\title{
Fitness-associated consequences of an omnivorous diet for the mangrove tree crab Aratus pisonii
}

\author{
Megan E. Riley ${ }^{1, *}$, Margaret $\operatorname{Vogel}^{2}$, Blaine D. Griffen ${ }^{1,2}$ \\ ${ }^{1}$ Department of Biological Sciences, and ${ }^{2}$ Marine Science Program, University of South Carolina, Columbia, \\ South Carolina 29208, USA
}

\begin{abstract}
Omnivory is a widespread trophic strategy with variable impacts on survival and reproduction, even within closely related taxonomic groups. In coastal ecosystems experiencing extensive environmental changes, many decapod crustaceans employ omnivorous feeding strategies. Because animals initially respond to environmental changes with behavioral modifications that can alter their foraging habits, a mechanistic understanding of how diet influences fitness is essential to predict the impact of future environmental changes on species fitness and population dynamics. We investigated the impact of an omnivorous diet on the consumption, survivorship, physiological condition, and reproductive effort of the mangrove tree crab Aratus pisonii, a major mangrove consumer. A. pisonii engaged in compensatory feeding on plant material; crabs consumed more food and digested it less efficiently as the proportion of plant material in their diet increased. Although there were relatively few deaths, survival appeared to be negatively impacted by the consumption of large quantities of animal material and marginally negatively influenced by high levels of plant consumption. Physiological condition improved due to consumption of both plant and animal material, while only consumption of animal material increased reproductive investment. These results demonstrate that the opportunistic inclusion of animal material in the diet of A. pisonii significantly improves physiological condition and reproductive effort, and suggests that vitellogenic individuals cannot fully compensate for a lack of animal material in their diet by increasing plant consumption. This study provides a mechanistic framework to understand how potential diet changes by omnivorous crabs such as A. pisonii, which are facing numerous changes in their environment, may impact their fitness and population dynamics.
\end{abstract}

KEY WORDS: Diet - Opportunistic omnivory $\cdot$ Environmental change $\cdot$ Fitness $\cdot$ Reproduction $\cdot$ Crustacean

\section{INTRODUCTION}

Omnivory is a widespread feeding strategy seen in a diverse range of taxa. Invertebrates such as insects (Coll \& Guershon 2002) and crustaceans (e.g. Buck et al. 2003, Poon et al. 2010) commonly consume both plant and animal material. Many vertebrates, including lizards (Cooper \& Vitt 2002), mammals (e.g. Home \& Jhala 2009), birds (e.g. Carlisle et al. 2012), and fish (González-Bergonzoni et al. 2012), also exploit a combination of plant and animal food sources. These omnivorous feeding strategies can

*Corresponding author: riley.megan.e@gmail.com have variable impacts on survival, growth, and reproduction, which can be seen even within a single taxonomic group, such as crustaceans. For example, the generalist salt marsh crab Armases cinereum achieves higher growth rates on a mixed diet of plant and animal material than on monotypic diets of plant or animal material alone (Buck et al. 2003). The amphipod species Ampithoe valida and Cymadusa compta have significantly higher fecundity when consuming a mixture of algae and animal material than when consuming a diet of animal material alone. Conversely, the closely related amphipod Gammarus

() The authors 2014. Open Access under Creative Commons by Attribution Licence. Use, distribution and reproduction are unrestricted. Authors and original publication must be credited. 
mucronatus has comparable growth and survival on an algal-only and mixed algal and animal diet, as well as equivalent fitness on exclusively algal or animal diets, and on diets that mix the 2 food types (Cruz-Rivera \& Hay 2000a).

Due to the diversity of potential diet strategies and their variable impact on closely related species, it can be difficult to predict how changes in diet may influence growth and fitness. However, a mechanistic understanding of how diet influences these metrics is key in predicting how species and populations may respond to environmental changes. Organisms frequently respond to human-induced rapid environmental changes with behavioral modifications, including altered foraging, and this can lead to changes in population dynamics (Tuomainen \& Candolin 2011). For instance, blue crabs Callinectes sapidus in a contaminated estuary had reduced success capturing active prey items and consumed more algae, sediment, and detritus than those from an uncontaminated reference site (Reichmuth et al. 2009). Additionally, the presence of the invasive Asian shore crab Hemigrapsus sanguineus forced the European green crab Carcinus maenas, a previously established invader, to decrease its mussel consumption and increase its consumption of red algae, a less preferable food source (Griffen et al. 2008). This foraging shift to an algal-dominated diet is concurrent with reduced fecundity in C. maenas, and is likely a contributing factor to the regional replacement of C. maenas by H. sanguineus (Griffen et al. 2011).

Human-induced rapid environmental changes, such as habitat loss, exotic species introductions, human harvesting, pollution, and climate change, are widespread in coastal habitats (e.g. Valiela et al. 2001, Roessig et al. 2004, Molnar et al. 2008, Rabalais et al. 2009). Decapod crustaceans are ecologically and economically important components of these coastal systems. Crabs in these habitats can function as ecosystem engineers through their burrowing and bioturbation activities (Kristensen 2008), by mediating nutrient turnover and retention (e.g. Olafsson et al. 2002, Needham et al. 2011), by impacting primary production (e.g. Holdredge et al. 2010), and by driving tree recruitment patterns in tropical coastal forests (Lindquist et al. 2009). Many of these ecological functions are associated with crab diet or foraging strategy. Few crabs engage in exclusively herbivorous or exclusively carnivorous trophic behavior, instead displaying a range of omnivorous feeding strategies. Predatory crabs commonly consume plant and algal material (e.g. Paul 1981, Ropes 1987, Kneib \& Weeks 1990), and crabs that are considered herbi- vorous actually incorporate large amounts of animal material in their diet (e.g. Dahdouh-Guebas et al. 1999, Samson et al. 2007).

The mangrove tree crab Aratus pisonii is one such omnivorous crustacean. This arboreal crab is abundant in neotropical mangrove systems (Beever et al. 1979, Diaz \& Conde 1988, Erickson et al. 2003), where it is distinctive in that it forages on fresh leaf tissue in the canopy rather than on leaf litter. $A$. pisonii is the primary herbivore of the red mangrove Rhizophora mangle (Feller \& Chamberlain 2007, Feller et al. 2013), and its herbivory can account for over $40 \%$ of total leaf damage in monotypic red mangrove stands (Erickson et al. 2003). As a result, these crabs provide a key link between mangrove primary production and the detrital food web, and contribute to both nutrient and biomass outwelling from mangrove systems (Beever et al. 1979). Fresh red mangrove leaves compose an estimated $84 \%$ of the diet of adult $A$. pisonii under natural settings (Erickson et al. 2003), but the crabs commonly supplement their plant diet with opportunistic scavenging and predation on insects, benthic infauna, and juvenile conspecifics (Warner 1967, Beever et al. 1979, Diaz \& Conde 1988). Feeding assays indicate that like many crustaceans, these crabs preferentially consume animal material over plant material, including red mangrove leaves (Erickson et al. 2008).

Three current and impending environmental changes are likely to alter foraging strategies of Aratus pisonii. The first is ocean acidification. Crustaceans respond to acidic conditions by increasing calcification -in effect becoming bigger, more robust individuals (Ries et al. 2009). Predatory capabilities of crustaceans commonly scale with individual size and claw strength (Seed \& Hughes 1995). We may therefore expect $A$. pisonii to incorporate more animal tissue in its diet as ocean acidification progresses, although it remains uncertain to which extent ocean acidification will enhance calcification of primarily terrestrial species, like $A$. pisonii, that spend limited time submerged. The second environmental change is pollution, which reduces crab foraging capabilities, resulting in a diet shift away from predation (Reichmuth et al. 2009). The Indian River Lagoon on the eastern coast of Florida, USA, where our study was conducted, currently experiences intense pollution (Qian et al. 2007). While public awareness of the effects of this pollution have focused primarily on mammals, birds, and reptiles, crustaceans may also experience negative impacts that could shift their diets away from animal consumption. The third environmental change that may alter diet is climate 
change. Many species are shifting their ranges in response to climate change (Hoegh-Guldberg \& Bruno 2010), and these range shifts can at times force these species to utilize habitats that they otherwise would not choose to inhabit. Thus if $A$. pisonii expands its range northward beyond the presence of mangrove habitat, it would be forced in these areas to consume alternative diets because of the physical absence of its normal diet of mangrove leaves.

The goal of this study was to investigate the link between diet, physiological condition, and fitness in the mangrove tree crab Aratus pisonii. Should qualitative or quantitative foraging changes occur in this omnivorous mangrove crab in response to the current or future environmental changes highlighted above, understanding the link between diet and fitness will allow us to predict population implications of these diet changes. Thus, we performed a controlled diet experiment to examine the impact of diet quality (proportion of plant to animal tissue) and diet quantity on A. pisonii consumption, assimilation efficiency, physiological condition, and fitness (reproduction and survivorship).

\section{MATERIALS AND METHODS}

\section{Experimental design and diet preparation}

We used a modified geometric analysis design (Simpson \& Raubenheimer 1995) that orthogonally varied both diet quality (proportion of plant to animal tissue in the diet) and diet quantity (proportion of crab body weight offered). This design incorporated 5 levels of diet quality with different amounts of plant to animal material $(100: 0,75: 25,50: 50,25: 75$, and $0: 100 \%$ by weight) and 4 diet quantities $(2,3,5$, and $11 \%$ of crab dry body weight per day). Crabs generally consume between 1.5 and $3 \%$ of their dry body weight per day (e.g. Olafsson et al. 2002), so these diet quantities spanned a range from limited to abundant food conditions. Each combination of diet quality and quantity was replicated twice for a total sample size of 40 individuals. We were interested in the actual diet consumed, which cannot be controlled or replicated (i.e. individual diet choice would cause 10 crabs with identical food choices to consume 10 unique diets over the $6 \mathrm{wk}$ experiment, leading to 10 unique diet treatments rather than 10 replicates of the same treatment). However, the diet offered can be controlled and replicated, and can be used to maximize diet variation. We therefore elected to use a regression-type experimental design to maximize diet variation with our experimental treatments rather than increase replication of a more limited range of offered diets. The analyses described hereafter also reflect this strategy.

Red mangrove leaves, which account for the majority of the natural diet of Aratus pisonii (Erickson et al. 2003), served as the plant material in our study. House crickets Achetus domesticus were offered as animal tissue. A. pisonii feed on insects, including crickets, in the field (Beever et al. 1979) and prefer $A$. domesticus to fresh plant and algal material in laboratory feeding assays (Erickson et al. 2008). In order to ensure that crabs consumed the desired proportion of plant to animal tissue, the 2 food types were mixed and embedded in an agar substrate in the 5 proportions of plant to animal material described previously. Freshly picked red mangrove leaves were collected from Avalon State Park in St. Lucie County, Florida, in June 2012. Live A. domesticus were obtained from commercial sources and euthanized by freezing. Both food types were then placed in a drying oven at $68^{\circ} \mathrm{C}$ until they reached a constant dry weight. They were ground separately into a fine powder using a Coffee-mate ${ }^{\circledR}$ coffee grinder and mixed to produce the 5 ratios of plant to animal tissue described above. They were then incorporated into an artificial agar diet by combining $2.8 \%$ agar, $4.6 \%$ food powder mixture, and $92.6 \%$ boiling deionised water by weight. This mixture was poured into $2.05 \mathrm{~cm}^{3}$ plastic molds, which were placed in a drying oven at $68^{\circ} \mathrm{C}$ until they reached a constant weight and formed dried agar cubes.

\section{Experimental setup and maintenance}

Adult female Aratus pisonii (carapace width, CW: 17 to $24 \mathrm{~mm}$ ) were collected from Avalon State Park in June 2012 and transported to the wet lab at the Smithsonian Marine Station at Fort Pierce, Florida. Each crab was placed into an individual plastic aquarium $(22.8 \mathrm{~cm}$ length $\times 15.2 \mathrm{~cm}$ width $\times 16.5 \mathrm{~cm}$ height $)$ with a $400 \mathrm{ml}$ glass finger bowl containing approximately 200 to $300 \mathrm{ml}$ of filtered seawater (salinity $\sim 31$ ppt). They were maintained for 3 to $4 \mathrm{~d}$ without food to standardize hunger levels and clear their guts prior to the start of the experiment. Total dry weight of experimental crabs was estimated based on initial CW at the time of collection using a previously established relationship between CW and dry weight (adj $\mathrm{R}^{2}=0.822$, $\mathrm{p}<0.001, \mathrm{n}=20$, M. Riley unpubl. data). This estimated dry weight was subsequently used to determine the precise amount of food to offer each crab. 
The experiment consisted of a $3 \mathrm{~d}$ diet cycle that was repeated 14 times for a total experimental duration of $6 \mathrm{wk}$. Diet cubes of the appropriate diet quality were shaved down to within $\pm 0.005 \mathrm{~g}$ of the assigned weight for each crab, and then offered to crabs for $48 \mathrm{~h}$. After that time, any remaining uneaten food was removed and seawater in finger bowls was refilled to its original volume to account for evaporative water loss. Crabs were then maintained without food for $24 \mathrm{~h}$ to allow for digestion and fecal production, after which the contents of each experimental chamber were poured into a flask attached to a vacuum pump and rinsed through Whatman® qualitative filter paper (Grade 1, $11 \mu \mathrm{m}$ particle size retention) to collect feces. Aratus pisonii were then offered fresh diet cubes, and a new feeding cycle was initiated. Uneaten food was dried at $68^{\circ} \mathrm{C}$ until it reached a constant dry weight to remove any humidity or water that the cubes may have absorbed from the finger bowls. Filter papers with collected feces were also dried at $68^{\circ} \mathrm{C}$ and weighed to quantify fecal production.

\section{Sample processing}

At the conclusion of the experiment, crabs were frozen at $-80^{\circ} \mathrm{C}$ and dissected within $3 \mathrm{mo}$. In order to determine the relative physiological condition of individual crabs, the main energy storage organ, the hepatopancreas (O'Connor \& Gilbert 1968, Parvathy 1971), was removed from the crab body. Similarly, the ovaries were isolated from the remainder of the crab body in order to determine reproductive investment of individual crabs. The hepatopancreas, ovaries, and remainder of the body were dried to a constant weight at $68^{\circ} \mathrm{C}$. Dry weight of the hepatopancreas as a proportion of the total dry body weight (i.e. the hepatosomatic index, HSI) was used as a mass-specific metric of investment in the main energy storage organ. Similarly, the dry weight of the ovaries as a proportion of the total dry body weight (i.e. the gonadosomatic index, GSI) was used as a mass-specific metric of reproductive investment.

\section{Statistical analyses}

Mean food consumption ( $\mathrm{g}$ ) was during a $3 \mathrm{~d}$ feeding cycle calculated by averaging the dry weight of the food consumed during each of the 14 feeding cycles (determined using the difference between initial and final food weight in each feeding period). To eliminate any potential influence of starvation on diet consumption (see Cronin \& Hay 1996) during the first feeding cycle, consumption values from the first feeding cycle were not included in this average. To standardize mean food consumption by crab body weight, the amount of food consumed during each feeding cycle was divided by the dry weight of the crab's body (g). Additionally, standardized mean food consumption was divided by 3 (due to the $3 \mathrm{~d}$ feeding cycle) to calculate standardized mean daily food consumption. Although feeding was limited to $2 \mathrm{~d}$ within the feeding cycle, we calculated daily consumption based on the entire length of the $3 \mathrm{~d}$ feeding cycle. Standardized mean daily plant and animal consumption were calculated by multiplying the standardized mean daily food consumption by the percentage of the diet $(0,25,50,75$, or $100 \%)$ that was plant or animal material, respectively.

Assimilation efficiency was calculated using the amount of feces produced during each feeding period in the formula: [total weight of food consumed (g) - total weight of feces produced $(\mathrm{g})$ ] / total weight of food consumed $(\mathrm{g})$. The resulting values were averaged and converted to percentages to calculate mean assimilation efficiency ( $\%$ of food consumed that was assimilated) by individual crabs. Four of the experimental crabs consistently placed food pellets into the finger bowls of water, breaking down the food pellets and making it difficult to distinguish uneaten food from disassociated feces. To avoid biasing our results by inadvertently mistaking food and feces, we eliminated these 4 crabs from the analyses.

The influence of diet quality and diet quantity treatments on standardized mean daily food consumption was determined using a general linear model with percentage of plant material in the diet and percentage of dry crab body weight offered per day as predictor variables. The influence of diet on assimilation efficiency was determined using a general linear model with mean daily plant consumption and mean daily animal consumption as continuous predictor variables.

The influence of diet on survivorship was determined using a logistic regression; occurrence of death was the response variable, and mean daily plant consumption and mean daily animal consumption were used as predictor variables. Although all crabs were included in our analyses of survivorship ( $\mathrm{n}=36$ ), our analyses of physiological condition and reproductive effort were restricted to crabs that survived the duration of the experiment $(n=29)$. The influence of diet on physiological condition (approximated by the HSI) was determined using a general linear model with 
mean daily plant consumption and mean daily animal consumption as continuous predictor variables. Due to the relatively high molting frequency of this species (every 53 d, Warner 1967), molting was also included as a categorical factor in this linear model. Similarly, the influence of diet on reproductive effort (approximated by the GSI) was determined using a general linear model with mean daily plant consumption and mean daily animal consumption as continuous predictor variables. Zoeal release was included as a categorical factor in the model; due to year-round reproductive output in this species (Warner 1967), 17 crabs were gravid at the start of the experiment and released zoeae 2 to $26 \mathrm{~d}$ after the experiment began (mean $\pm \mathrm{SD}=10 \pm 6 \mathrm{~d}, \mathrm{n}=17$ ). Two models were developed and are presented for the GSI: one that included all surviving crabs $(n=29)$, and one in which the single crab in the experiment with late-stage developing ovaries was removed $(\mathrm{n}=$ 28). This particular crab was maintained on a mixed diet of $25: 75 \%$ plant to animal material and offered $8 \%$ of its body weight per day, and as a result of the advanced stage of its ovary development, its GSI was very high relative to the remainder of the experimental crabs (i.e. it was in late-stage vitellogenesis at the conclusion of the experiment).

\section{RESULTS}

Aratus pisonii increased their mean daily food consumption as the proportion of plant material in their diet increased, but only under the abundant food conditions represented by the highest diet quantity treatment (adj $\mathrm{R}^{2}=0.678$, mean slope $\pm \mathrm{SE}=4.23 \pm$ $1 \%, t=4.23, \mathrm{p}=0.003$, Fig. 1). On average, crabs offered 2,3 , and $5 \%$ of their body weight consumed $1.68,2.86$, and $4.71 \%$ of their body weight daily, irrespective of the proportion of plant and animal material in their diet (Fig. 1). In the $11 \%$ body weight treatment, crabs offered only animal material consumed an average of $5.10 \%$ of their body weight daily (Fig. 1). When crabs in the same diet quantity treatment were offered a 50:50\% mixture of plant:animal material or plant material alone, they increased their standardized mean daily consumption to 6.75 and $9.50 \%$, respectively (Fig. 1).

Assimilation efficiency (percentage of consumed food that was assimilated) decreased with daily consumption of plant material (Fig. 2A) and increased with daily consumption of animal material (Fig. 2B; adj $\mathrm{R}^{2}=0.675$; plant, mean slope $\pm \mathrm{SE}=-252 \pm$ $52.4 \%, t=-4.80, \mathrm{p}<0.001$; animal, mean slope $\pm \mathrm{SE}=$
$298 \pm 90.1 \%, t=3.31, \mathrm{p}=0.003)$. Specifically, Aratus pisonii assimilated $57.9 \pm 0.227 \%$ (mean $\pm \mathrm{SE}$ ) of the exclusively animal diet, while individuals maintained on an all-plant diet assimilated $23.8 \pm 0.314 \%$ of the food they consumed (Fig. 2).

Crab survivorship decreased with daily animal consumption (mean $\pm \mathrm{SE}=-42.1 \pm 19.9, z=-2.11$, $\mathrm{p}=0.034$ ) and was marginally negatively influenced by daily plant consumption $(z=-1.88, \mathrm{p}=0.060)$. Molting did not affect energy storage in the hepatopancreas $(t=-0.789, \mathrm{p}=0.437$; Fig. 3$)$, but Aratus pisonii physiological condition, as determined by the HSI, improved by $23.8 \%$ with each $1 \%$ of their body weight that crabs consumed in plant material each day (Fig. 3A) and increased by $148 \%$ with each $1 \%$ of their body weight that they consumed in animal material each day (Fig. 3B; adj $\mathrm{R}^{2}=0.692$; plant, mean slope $\pm \mathrm{SE}=23.8 \pm 10.2 \%, t=2.33, \mathrm{p}=0.028$; animal, mean slope $\pm \mathrm{SE}=148 \pm 20.7 \%, t=7.17, \mathrm{p}<0.001)$.

When all surviving crabs were included in the analysis to determine how diet influences reproductive effort, zoeal release had no impact on subsequent reproductive effort $(t=-1.122, \mathrm{p}=0.273)$. Investment in ovary development was unaffected by plant consumption ( $t=0.632, \mathrm{p}=0.533)$, but Aratus pisonii increased their reproductive effort by $51.7 \%$ with every $1 \%$ of their body weight that they consumed in animal material each day (adj $\mathrm{R}^{2}=0.353$, mean slope $\pm \mathrm{SE}=51.7 \pm 12.9 \%, t=4.01, \mathrm{p}<0.001$ ). When the single crab with late-stage developing ovaries was removed, investment in ovary development remained unaffected by previous zoeal release $(t=-0.078, \mathrm{p}=0.938 ;$ Fig. 4$)$ or plant consumption $(t=$ $0.173, \mathrm{p}=0.864 ;$ Fig. $4 \mathrm{~A})$; however, without this single individual, the effect of diet on reproductive

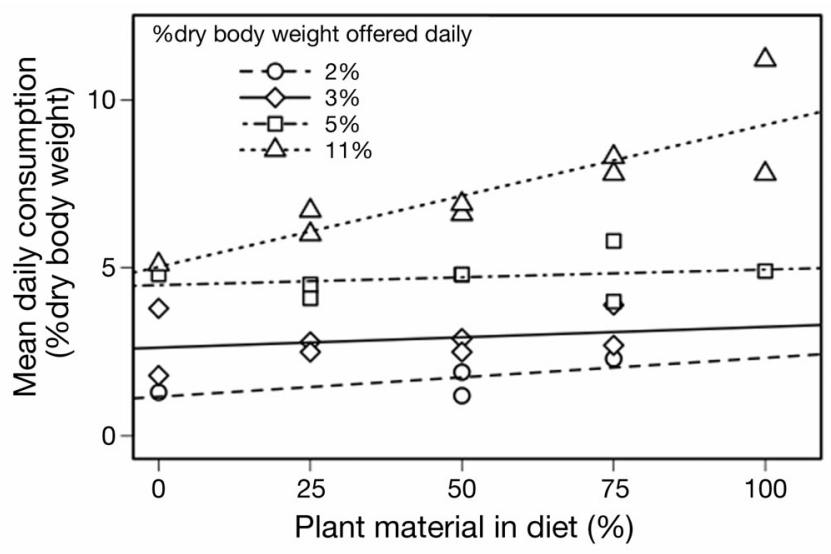

Fig. 1. Aratus pisonii. Changes in mean daily food consumption as a function of diet quality (percentage of plant material in diet) and quantity (percentage of crab dry body weight) offered 

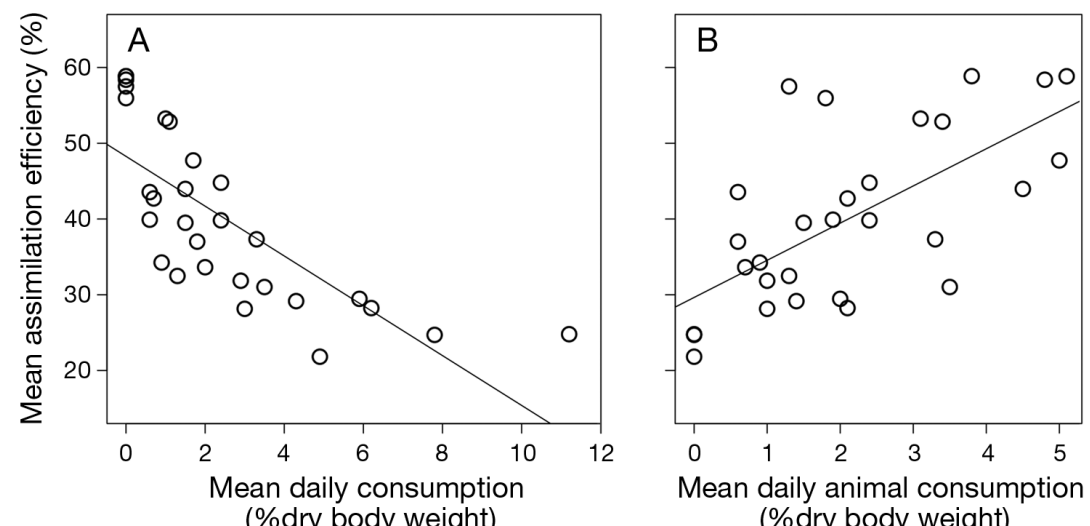

Fig. 2. Aratus pisonii. Relationship between assimilation efficiency (\%) and mean daily consumption of (A) plant and (B) ani-mal material
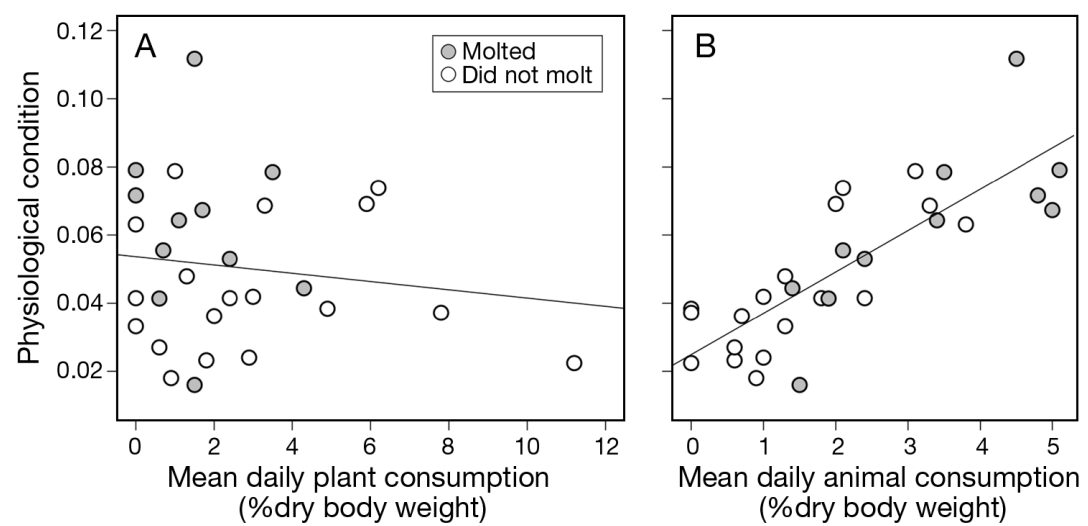

(\%dry body weight)

Fig. 3. Aratus pisonii. Physiological condition (as measured by the hepatosomatic index) as a function of mean daily consumption of (A) plant and (B) animal material
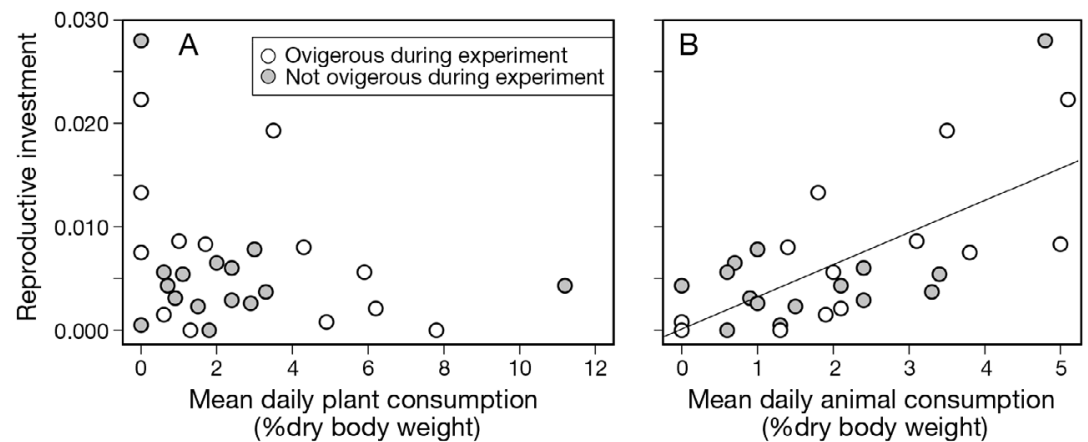

Fig. 4. Aratus pisonii. Reproductive effort (as measured by the gonadosomatic index) as a function of mean daily consumption of (A) plant and (B) animal material

effort became less extreme so that $A$. pisonii increased their reproductive effort by $31.8 \%$ with every $1 \%$ of their body weight that they consumed in animal material each day (adj $\mathrm{R}^{2}=0.392$, mean slope $\pm \mathrm{SE}=31.8 \pm 8.07 \%, t=3.94, \mathrm{p}<0.001$, Fig. $4 \mathrm{~B})$.

\section{DISCUSSION}

In this study, we investigated the impact of diet quality (proportion of plant to animal material) and diet quantity on the feeding strategy, physiological condition, and fitness of the mangrove tree crab Aratus pisonii, an omnivorous crab common in neotropical mangroves. A. pisonii demonstrated strong evidence of compensatory feeding on plant material when maintained in abundant food conditions by increasing their food consumption as the plant material in their diet increased. This behavior is likely meant to compensate for the low nutritional quality of plant material, which contains high levels of indigestible material such as lignin and cellulose, as well as low levels of nitrogen and organic matter relative to animal tissue (Mattson 1980, Wolcott \& O'Connor 1992, Linton \& Greenaway 2007). Red mangrove leaves, the plant material used in this study, contain particularly high levels of condensed tannins (20-40\% dry weight) as well as other secondary metabolites that are difficult to digest and may negatively impact consumer condition (Hernes et al. 2001, Erickson et al. 2004).

Despite the poor nutritional quality of plant material relative to animal material, many herbivorous crabs are extremely efficient at assimilating the plant tissue in their diet. For example, the mangrove crab Neosarmatium meinerti assimilates over $80 \%$ of the dry weight of fresh Avicennia marina mangrove leaves in its diet (Emmerson \& McGwynne 1992). In contrast, Aratus pisonii was relatively inefficient at assimilating plant material in the present study, and crabs maintained on a diet of all-plant material assimilated just $23.8 \%$ of the food they consumed. There is some indication in the literature that assimilation of senescent leaves is different than that of fresh leaves (e.g. Greenaway \& Raghavan 1998). By necessity of our experimental design, we dried and ground fresh Rhizophora mangle leaves before incorporating them in the agar-based diet, which could have altered the crabs' ability to assimilate the plant material. However, the animal material was similarly processed and crabs confined to an all-animal diet 
assimilated $57.9 \%$ of the food they consumed, more than twice the amount assimilated by those on an allplant diet. A. pisonii's inefficient assimilation of plant material relative to animal material may partially explain the compensatory increase in crab food consumption that was seen as the amount of plant material in the diet increased.

Survivorship throughout the experiment was negatively impacted by daily animal consumption and marginally negatively influenced by plant consumption. However, there were relatively few mortality events $(n=7)$, and the described trend was likely driven by the death of 2 crabs with high daily animal consumption and a single crab with high daily plant consumption. Diet quality has been shown to have a mixed impact on the survivorship of other crustaceans, such as amphipods, whose survivorship on diets that mix high- and low-quality food sources varies widely depending on the species (Cruz-Rivera \& Hay 2000a,b), and diet quantity is inversely correlated with longevity in a variety of species (e.g. Lawler et al. 2008, Pietrzak et al. 2010). Alternatively, the inclusion of nitrogen-rich animal tissue in its diet significantly improved the reproductive investment and physiological condition of Aratus pisonii. Nitrogen is an essential requirement for crustacean growth (i.e. molting; Skinner 1966, Chang 1995) and reproduction. Because egg production in some species of brachyuran crabs can equal or exceed $10 \%$ of dry body weight, the nitrogen needed for a single reproductive event can be considerable (Gifford 1962, Hines 1982, 1992). This may explain the demonstrated increase in A. pisonii reproductive effort (as measured by the GSI) with daily animal consumption. Gonad biomass in crustaceans is directly proportional to the quantity of eggs produced (Hartnoll 2006, Griffen 2013), so this increase in gonad development should translate directly to increased fecundity and reproductive output in A. pisonii. Recent reproductive investment by crabs that were gravid upon collection from the field and subsequently released broods had no impact on their reproductive effort at the conclusion of this experiment. This is consistent with another report for this species, in which brood size remained constant for females over several reproductive events (Leme 2006). Likewise, plant consumption had no impact on reproductive effort, providing evidence that crabs undergoing vitellogenesis cannot fully compensate for a lack of animal material in their diet by increasing plant consumption.

Both plant and animal consumption significantly improved physiological condition (as measured by the HSI), although consumption of protein-rich animal material had a $6.24 \times$ stronger positive impact on investment in the hepatopancreas than consumption of plant material. The hepatopancreas is the primary energy storage organ for crustaceans, particularly for long-term storage. It serves as one of several storage sites for glycogen, a source of quick energy, and is the main storage site for lipids, which are longerterm energy stores (O'Connor \& Gilbert 1968, Parvathy 1971, Chang 1995). Crabs increase lipid production as well as lipid storage in the hepatopancreas prior to molting, and previous studies have suggested that crabs rely on lipid stores in the hepatopancreas for molting (O'Connor \& Gilbert 1968, Chang 1995). However, molting had no significant impact on the HSI of Aratus pisonii, and several crabs in this experiment maintained large hepatopancreas masses following molting. A pisonii's lack of a discernible decrease in hepatopancreas mass following molting suggests that this species may rely on alternative energy stores, such as those in muscle tissue, to finance the molting process (Parvathy 1971).

In conclusion, this study demonstrates that even for a largely herbivorous consumer such as the mangrove tree crab Aratus pisonii, the opportunistic consumption of animal material significantly improves physiological condition and reproductive effort. While crabs were able to improve their physiological condition by consuming both plant and animal material, only consumption of animal material increased reproductive investment. Although there have been no documented diet shifts by A. pisonii to date, a number of environmental factors, including ocean acidification, pollution, and climate change, have the potential to directly influence their foraging behavior (see 'Introduction'). Because A. pisonii is an ecologically important consumer in neotropical mangrove systems, any changes in their population dynamics, either positive or negative, would also have important implications for the broader mangrove community (Feller et al. 2013). Additional work is needed to determine whether the mechanistic link established here between diet, physiology, and reproduction in A. pisonii applies to other species of omnivorous crabs that are ecologically and economically influential in coastal systems. In a rapidly changing environment in which species modify their behavior in response to environmental changes, understanding this link is essential for predicting the total impact of current and future environmental conditions.

Acknowledgements. We thank I. C. Feller for advice and insight into the study system. This research was supported by NSF grant no. OCE-1129166 and a Smithsonian Institu- 
tion/Link Foundation Graduate Fellowship. This is contribution no. 930 of the Smithsonian Marine Station at Fort Pierce, Florida.

\section{LITERATURE CITED}

Beever J, Simberloff D, King L (1979) Herbivory and predation by the mangrove tree crab Aratus pisonii. Oecologia 43:317-328

Buck T, Breed G, Pennings S, Chase M, Zimmer M, Carefoot $\mathrm{T}$ (2003) Diet choice in an omnivorous salt-marsh crab: different food types, body size and habitat complexity. J Exp Mar Biol Ecol 292:103-116

Carlisle JD, Olmstead KL, Richart CH, Swanson DL (2012) Food availability, foraging behavior, and diet of autumn migrant landbirds in the Boise foothills of southwestern Idaho. Condor 114:449-461

Chang ES (1995) Physiological and biochemical changes during the molt cycle in decapod crustaceans: an overview. J Exp Mar Biol Ecol 193:1-14

Coll M, Guershon M (2002) Omnivory in terrestrial arthropods: mixing plant and prey diets. Annu Rev Entomol 47 : 267-297

> Cooper WE Jr, Vitt LJ (2002) Distribution, extent, and evolution of plant consumption by lizards. J Zool (Lond) 257: 487-517

Cronin G, Hay M (1996) Susceptibility to herbivores depends on recent history of both the plant and animal. Ecology 77:1531-1543

Cruz-Rivera E, Hay M (2000a) The effects of diet mixing on consumer fitness: macroalgae, epiphytes, and animal matter as food for marine amphipods. Oecologia 123:252-264

> Cruz-Rivera E, Hay M (2000b) Can quantity replace quality? Food choice, compensatory feeding, and fitness of marine mesograzers. Ecology 81:201-219

Dahdouh-Guebas F, Giuggioli M, Oluoch A, Vannini M, Cannicci S (1999) Feeding habits of non-ocypodid crabs from two mangrove forests in Kenya. Bull Mar Sci 64: 291-297

$>$ Diaz H, Conde J (1988) On the food sources for the mangrove tree crab Aratus pisonii (Brachyura: Grapsidae). Biotropica 20:348-350

Emmerson W, McGwynne L (1992) Feeding and assimilation of mangrove leaves by the crab Sesarma meinerti de Man in relation to leaf-litter production in Mgazana, a warm temperate southern African mangrove swamp. J Exp Mar Biol Ecol 157:41-53

Erickson A, Saltis M, Bell S, Dawes C (2003) Herbivore feeding preferences as measured by leaf damage and stomatal ingestion: a mangrove crab example. J Exp Mar Biol Ecol 289:123-138

Erickson A, Bell S, Dawes C (2004) Does mangrove leaf chemistry help explain crab herbivory patterns? Biotropica 36:333-343

Erickson A, Feller I, Paul V, Kwiatkowski L, Lee W (2008) Selection of an omnivorous diet by the mangrove tree crab Aratus pisonii in laboratory experiments. J Sea Res 59:59-69

Feller IC, Chamberlain A (2007) Herbivore responses to nutrient enrichment and landscape heterogeneity in a mangrove ecosystem. Oecologia 153:607-616

Feller IC, Chamberlain AH, Piou C, Chapman S, Lovelock CE (2013) Latitudinal patterns of herbivory in mangrove forests: consequences of nutrient over-enrichment. Ecosystems 16:1203-1215

Gifford CA (1962) Some observations on the general biology of the land crab, Cardisoma guanhumi (Latreille), in south Florida. Biol Bull (Woods Hole) 123:207-223

González-Bergonzoni I, Meerhoff M, Davidson TA, Teixeirade Mello F, Baattrup Pederson A, Jeppesen E (2012) Meta-analysis shows a consistent and strong latitudinal pattern in fish omnivory across ecosystems. Ecosystems 15:492-503

Greenaway P, Raghavan S (1998) Digestive strategies in two species of leaf-eating land crabs (Brachyura: Gecarcinidae) in a rain forest. Physiol Zool 71:36-44

Griffen BD (2014) Linking individual diet variation and fecundity in an omnivorous marine consumer. Oecologia 174:121-130

> Griffen BD, Guy T, Buck JC (2008) Inhibition between invasives: a newly introduced predator moderates the impacts of a previously established invasive predator. J Anim Ecol 77:32-40

> Griffen BD, Altman I, Hurley J, Mosblack H (2011) Reduced fecundity by one invader in the presence of another: a potential mechanism leading to species replacement. J Exp Mar Biol Ecol 406:6-13

Hartnoll RG (2006) Reproductive investment in Brachyura. Hydrobiologia 557:31-40

> Hernes PJ, Benner R, Cowie GI, Goni MA, Bergamaschi BA, Hedges JI (2001) Tannin diagenesis in mangrove leaves from a tropical estuary: a novel molecular approach. Geochim Cosmochim Acta 65:3109-3122

Hines AH (1982) Allometric constraints and variables of reproductive effort in brachyuran crabs. Mar Biol 69:309-320

Hines AH (1992) Constraint on reproductive output in brachyuran crabs: pinnotherids test the rule. Am Zool 32:503-511

Hoegh-Guldberg O, Bruno JF (2010) The impact of climate change on the world's marine ecosystems. Science 328: 1523-1528

> Holdredge C, Bertness MD, Herrmann NC, Gedan KB (2010) Fiddler crab control of cordgrass primary production in sandy sediments. Mar Ecol Prog Ser 399:253-259

Home C, Jhala YV (2009) Food habits of the Indian fox (Vulpes bengalensis) in Kutch, Gujarat, India. Mamm Biol 74:403-411

Kneib RT, Weeks CA (1990) Intertidal distribution and feeding-habits of the mud crab Eurytium limosum. Estuaries 13:462-468

Kristensen E (2008) Mangrove crabs as ecosystem engineers with emphasis on sediment processes. J Sea Res 59: 30-43

Lawler DF, Larson BT, Ballam JM, Smith GK and others (2008) Diet restriction and ageing in the dog: major observations over two decades. Br J Nutr 99:793-805

Leme MHA (2006) Investimento reprodutivo e produção de ovos em desovas consecutivas do caranguejo Aratus pisonii (H. Milne Edwards) (Crustacea, Brachyura, Grapsoidea). Rev Bras Zool 23:727-732

Lindquist ES, Krauss KW, Green PT, O'Dowd DJ, Sherman PM, Smith TJ (2009) Land crabs as key drivers in tropical coastal forest recruitment. Biol Rev Camb Philos Soc 84: 203-223

> Linton SM, Greenaway P (2007) A review of feeding and nutrition of herbivorous land crabs: adaptations to low quality plant diets. J Comp Physiol B 177:269-286

Mattson WJ (1980) Herbivory in relation to plant nitrogen content. Annu Rev Ecol Syst 11:119-161

Molnar JL, Gamboa RL, Revenga C, Spalding MD (2008) Assessing the global threat of invasive species to marine biodiversity. Front Ecol Environ 6:485-492

Needham HR, Pilditch CA, Lohrer AM, Thrush SF (2011) 
Context-specific bioturbation mediates changes to ecosystem functioning. Ecosystems 14:1096-1109

O'Connor JD, Gilbert LI (1968) Aspects of lipid metabolism in crustaceans. Am Zool 8:529-539

Olafsson E, Buchmayer S, Skov M (2002) The East African decapod crab Neosarmatium meinerti (de Man) sweeps mangrove floors clean of leaf litter. Ambio 31:569-573

Parvathy K (1971) Glycogen storage in relation to the molt cycle in two crustaceans Emerita asiatica and Ligia exotica. Mar Biol 10:82-86

Paul RKG (1981) Natural diet, feeding and predatory activity of the crabs Callinectes arcuatus and C. toxotes (Decapoda, Brachyura, Portunidae). Mar Ecol Prog Ser 6:91-99

Pietrzak B, Grzesiuk M, Bednarska A (2010) Food quantity shapes life history and survival strategies in Daphnia magna. Hydrobiologia 643:51-54

Poon DYN, Chan BKK, Williams GA (2010) Spatial and temporal variation in diets of the crabs Metopograpsus frontalis (Grapsidae) and Perisesarma bidens (Sesarmidae): implications for mangrove food webs. Hydrobiologia 638:29-40

Qian Y, Migliaccio KW, Wan Y, Li Y (2007) Trend analysis of nutrient concentrations and loads in selected canals of the southern Indian River Lagoon, Florida. Water Air Soil Pollut 186:195-208

Rabalais NN, Turner RE, Diaz RJ, Justić D (2009) Global change and eutrophication of coastal waters. ICES J Mar Sci 66:1528-1537

Reichmuth JM, Roudez R, Glover T, Weis JS (2009) Differences in prey capture behavior in populations of blue crab (Callinectes sapidus Rathbun) from contaminated and clean estuaries in New Jersey. Estuar Coast 32:298-308

Editorial responsibility: Bernard Sainte-Marie, Mont-Joli, Quebec, Canada
Ries JB, Cohen AL, McCorkle DC (2009) Marine calcifiers exhibit mixed responses to $\mathrm{CO}_{2}$ induced ocean acidification. Geology 37:1131-1134

> Roessig JM, Woodley CM, Cech JJ, Hansen JL (2004) Effects of global climate changes on marine and estuarine fishes and fisheries. Rev Fish Biol Fish 14:251-275

Ropes JW (1987) The food habits of five crab species at Pettaquamscutt River, Rhode Island. Fish Bull 87: 197-204

Samson AS, Yokota M, Strussmann CA, Watanabe S (2007) Natural diet of grapsoid crab Plagusia dentipes de Haan (Decapoda: Brachyura: Plagusiidae) in Tateyama Bay, Japan. Fish Sci 73:171-177

Seed R, Hughes RN (1995) Criteria for prey size-selection in molluscivorous crabs with contrasting claw morphologies. J Exp Mar Biol Ecol 193:177-195

Simpson S, Raubenheimer D (1995) The geometric analysis of feeding and nutrition: a user's guide. J Insect Physiol 41:545-553

Skinner DM (1966) Breakdown and reformation of somatic muscle during the molt cycle of the land crab Gecarcinus lateralis. J Exp Zool 163:115-123

Tuomainen U, Candolin U (2011) Behavioural responses to human-induced environmental change. Biol Rev Camb Philos Soc 86:640-657

Valiela I, Bowen J, York JK (2001) Mangrove forests: one of the world's threatened major tropical forests. Bioscience 51:807-815

> Warner GF (1967) The life history of the mangrove tree crab Aratus pisonii. J Zool 153:321-335

Wolcott D, O'Connor N (1992) Herbivory in crabs: adaptations and ecological considerations. Am Zool 32:370-381

Submitted: July 12, 2013; Accepted: October 28, 2013

Proofs received from author(s): December 4, 2013 